\title{
Analisis Pengaruh Perputaran Kas, Perputaran Piutang dan Perputaran Total Aset terhadap Profitabilitas pada Perusahaan Ritel di Indonesia
}

\author{
Muhamad Syahwildan ${ }^{1 *}$, Irma Damayanti ${ }^{2)}$ \\ ${ }^{1 *)}$ Program Studi Manajemen, FEBIS, Universitas Pelita Bangsa \\ 2) Program Studi Magister Manajemen, FEBIS, Universitas Pelita Bangsa \\ Cikarang Utara, Kab.Bekasi, Indonesia, 17530 \\ E-mail: Muhamad.syahwildan@pelitabangsa.ac.id ${ }^{*}$
}

\begin{abstract}
ABSTRAK
Tujuan dari penelitian ini adalah untuk menganalisis pengaruh perputatan kas, perputaran piutang dan perputaran total aset terhadap profitabilitas studi kasus pada perusahaan ritel yang terdaftar di BEI periode 2017-2019. Data yang digunakan adalah data sekunder dan metode yang digunakan adalah metode regresi data panel dengan menggunakan program Eviews versi 10, untuk memperoleh gambaran yang menyeluruh mengenai hubungan antar variabel satu dengan variabel yang lain. Sampel dalam penelitian ini terdiri dari 8 perusahaan sub sektor ritel (pedagang eceran) periode 2017-2019 yang diambil dari laporan keuangan per triwulan. Hasil penelitian ini menyatakan bahwa variabel Perputaran Total Aset (CTO) dan Perputaran Total Aset (TATO) secara parsial memiliki pengaruh negatif yang signifikan terhadap profitabilitas. Sedangkan Perputaran Piutang (ARTO) secara parsial tidak memiliki pengruh yang signifikan terhadap profitabilitas pada level of significance $>0,05$. Dengan hasil uji koefisien determinasi 88,24\%.
\end{abstract}

Kata kunci: Perputaran Kas; Perputaran Piutang; Perputaran Total Aset; Profitabilitas

\begin{abstract}
The purpose of this study is to analyze the effect of cash turnover, accounts receivable turnover and total asset turnover on the case study profitability of retail companies listed on the Indonesia Stock Exchange in the 2017-2019 period. The data used are secondary data and the method used is the panel data regression method using the Eviews version 10 program to obtain a comprehensive picture of the relationship between variables with other variables. The sample in this study consisted of 8 retail sub-sector companies (retail traders) for the 2017-2019 period taken from quarterly financial statements. The results of this study are that the Cash Turnover (CTO) and Total Assets Turnover (TATO) variables partially have a significant negative effect on profitability at the level of significance $<0.05$. While ARTO partially does not have a significant effect on profitability at the level of significance> 0.05. The results of the coefficient determination was have $88.24 \%$.
\end{abstract}

Keyword: Cash Turnover; Accounts Receivable Turnover; Total Assets Turnover; Profitability 


\section{PENDAHULUAN}

Perkembangan bisnis ditengah zaman moderen seperti sekarang ini, membuat setiap individu maupun perusahaan dituntut dapat mengikuti persaingan dan kondisi pasar. Persaingan dalam menciptakan nilai perusahaan serta mengelola faktor faktor internal secara efektif dan efiseien dengan tujuan utama yaitu menciptakan nilai profitabilitas atau keuntungan yang besar dalam usaha bisnisnya. Profitabilitas yang tinggi akan dapat mendukung kegiatan operasional secara maksimal. Tinggi rendahnya profitabilitas dipengaruhi oleh berbagai faktor diantaranya modal kerja, kas, piutang, total aset dan persediaan.

Berikut Data Pertumbuhan Penjualan Ritel Indonesia tetap berstatus aktif di CEIC dan dilaporkan oleh CEIC Data. Data dikategorikan dalam Global Economic Monitor World Trend Plus - Table: Retail Sales: Y-o-Y Growth: Monthly: Asia.

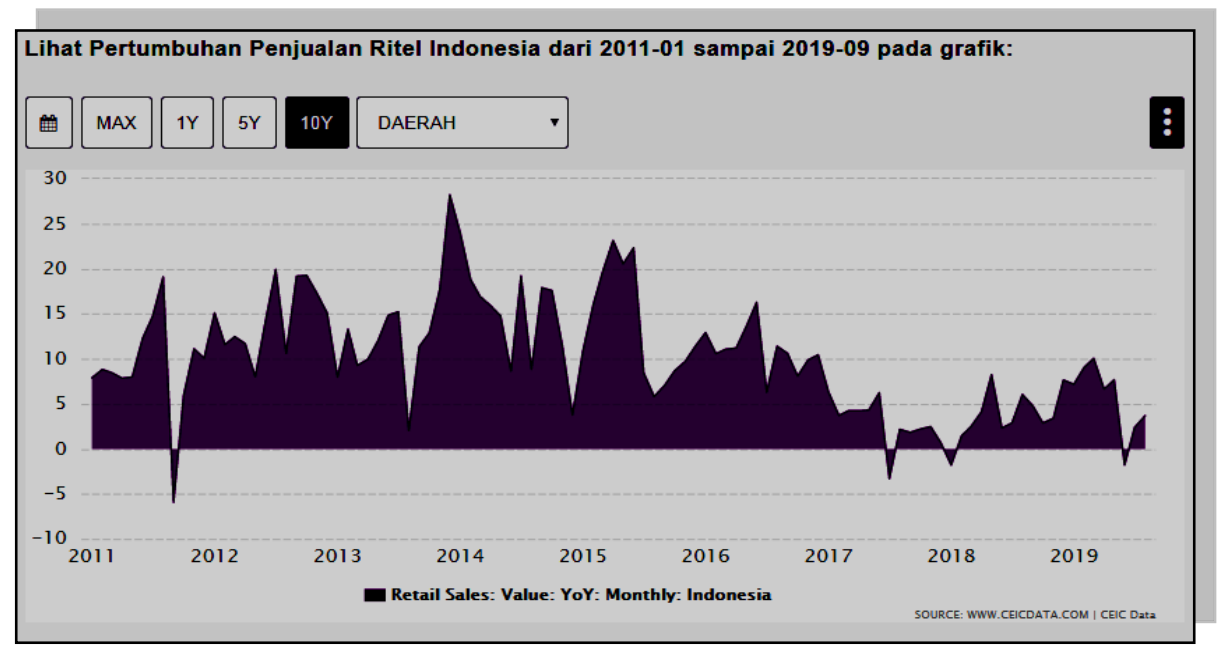

\section{Gambar 1. Pertumbuhan penjualan Ritel Indonesia} Sumber: WWW..CEICDATA.COM: CEIC Data

Data pertumbuhan penjualan ritel Indonesia ini diperbaharui setiap bulannya dengan rata-rata 9,7\% dari bulan Januari 2011 sampai dengan September 2019 dengan total 105 observasi. Dalam garfik ini didapatkan angka tertinggi yaitu mencapai 28,2\% pada bulan Desember 2013, serta rekor terendah mencapai $-5,9 \%$ pada Juli 2012. Namun 3 tahun terakhir tepatnya pada tahun 2018 pertumbuhan penjualan mengalami penurunan sebesar $3 \%$.

Fenomena yang terjadi 3 tahun belakangan ini, kita ketahui salah satunya adalah beberapa gerai perusahaan ritel makanan milik Hero supermarket melakukan penutupan di beberapa daerah, sebab Hero Grup mengalami penurunan penjualan 7\% menjadi Rp 10,8 
triliun. Pada tahun 2018 kerugian perusahaan naik drastis menjadi Rp 1,25 triliun. Inilah yang menyebabkan HERO grup harus menutup enam gerai supermarket yang tidak menghasilkan profit memuaskan, untuk mengurangi beban usaha dan juga pengeluaran kas operasional yang harus ditanggungnya. Disisi lain dalam penjualan produknya perusahaan ritel yang berperan sebagai grosir terbesar menjalankan usahanya dengan penjualan secara kredit, cara ini akan menimbulkan keuntungan sekaligus kerugian. Sebuah perusahaan ritel kecil maupun menengah yang tidak dapat membayar sekarang atas pembelian mereka akan melakukan pembayaran secara kredit untuk meringankan beban usahanya. Pendapatan dan laba perusahaan akan meningkat, tetapi kerugian yang akan dialami perusahaan terebut akan meningkat pula, karena meningkatnya jumlah piutang yang tidak dapat tertagih. Disatu sisi dalam pengelolaan suatu usaha, sebuah perusahaan juga perlu pengelolaan kas dan juga semua asset yang dimiliki secara maksimal, guna menunjang kegiatan operasional untuk menghasilkan profit. Disatu sisi peran pengelolaan kas operasional sangatlah penting, karena perputaran kas merupakan kemampuan kas untuk menghasilkan pendapatan atau profit sehingga dapat dilihat berapa kali uang kas berputar dalam satu periode tertentu.

Oleh karena itu untuk menganalisis variabel-variabel yang mempengaruhi profitabilitas suatu perusahaan, penulis mengambil variabel yang akan diuji ialah perputaran kas, perputaran piutang dan perputaran total asset terhadap profitabilitas. Penelitian ini didasarkan pada penelitian-penelitian sebelumnya yaitu penelitian yang dilakukan oleh Fibri dkk (2018) menyimpulkan bahwa perputaran modal kerja, perputaran piutang dan perputaran total asset berpengaruh positif dan signifikan terhadap profitabilitas, serta penelitian yang dilakukan oleh Dewi (2015) menyimpulkan bahwa perputaran modal kerja berpengaruh negatif terhadap profitabilitas, perputaran piutang tidak berpengaruh terhadap profitabilitas, sedangkan perputaran kas berpengaruh positif terhadap profitabilitas

Disatu sisi beberapa penelitian menghasilkan hasil yang berbanding terbalik dengan hasil yang telah dikemukan sebelumnya. Diantaranya yaitu penelitian yang dilakukan oleh Surya dkk (2017) menyimpulkan bahwa secara simultan maupun parsial perputaran kas dan perputaran persediaan tidak berpengaruh signifikan terhadap profitabilitas, serta sebuah penelitian yang dilakukan oleh Lucky dkk (2019) menyimpulkan perputaran piutang berpengaruh negatif dan tidak signifikan terhadap profitabilitas (ROA), begitu juga penelitian yang dilakukan oleh Natasha (2019) perputaran kas berpengaruh negatif terhadap tingkat laba. Sedangkan perputaran persediaan tidak memiliki pengaruh terhadap tingkat laba pada perusahaan. Dengan adanya fenomena kemunduran usaha ritel di Indonesia yang terjadi dan perbedaan hasil penelitian (Research Gap) pada penelitian-penelitian sebelumnya, maka 
mendorong bagi penulis untuk dilakukannya penelitian lebih lanjut mengenai pengaruh perputaran kas, perputaran piutang dan perpuataran total aset terhadap profitablitas perusahaan ritel di Indonesia.

\section{METODE PENELITIAN}

Metode analisis yang dipakai dalam penelitian ini adalah analisis regresi berganda yaitu analisis yang digunakan peneliti, bila bermaksud meramalkan bagaimana keadaan (naik turunnya) variabel dependen (kriterium), bila dua atau lebih variabel independen sebagai faktor prediktor dimanipulasi (dinaik turunkan nilainya).

Untuk menganalisis penelitian ini, peneliti mengujinya dengan menggunakan EViews versi 10 yaitu dengan menggunakan alat statistik regresi berganda dengan satu variabel tidak bebas $(\mathrm{Y})$ dan tiga variabel bebas $(\mathrm{X})$. Alat analisis ini digunakan dengan untuk melihat pengaruh beberapa variabel bebas terhadap variabel tidak bebas secara parsial.

Menurut pendapat Cresswell (2016), desain penelitian ditetapkan berdasarkan tujuan dan hipotesis penelitian Desain penelitian ini menggunakan pendekatan kuantitatif dengan jenis hubungan asosiatif kausalitas yaitu penelitian yang mencari hubungan (pengaruh) sebab akibat dari variabel independent atau variabel yang mempengaruhi (X) terhadap variabel dependen atau variabel yang dipengaruhi (Y). Berikut ini adalah desain penelitiannya.

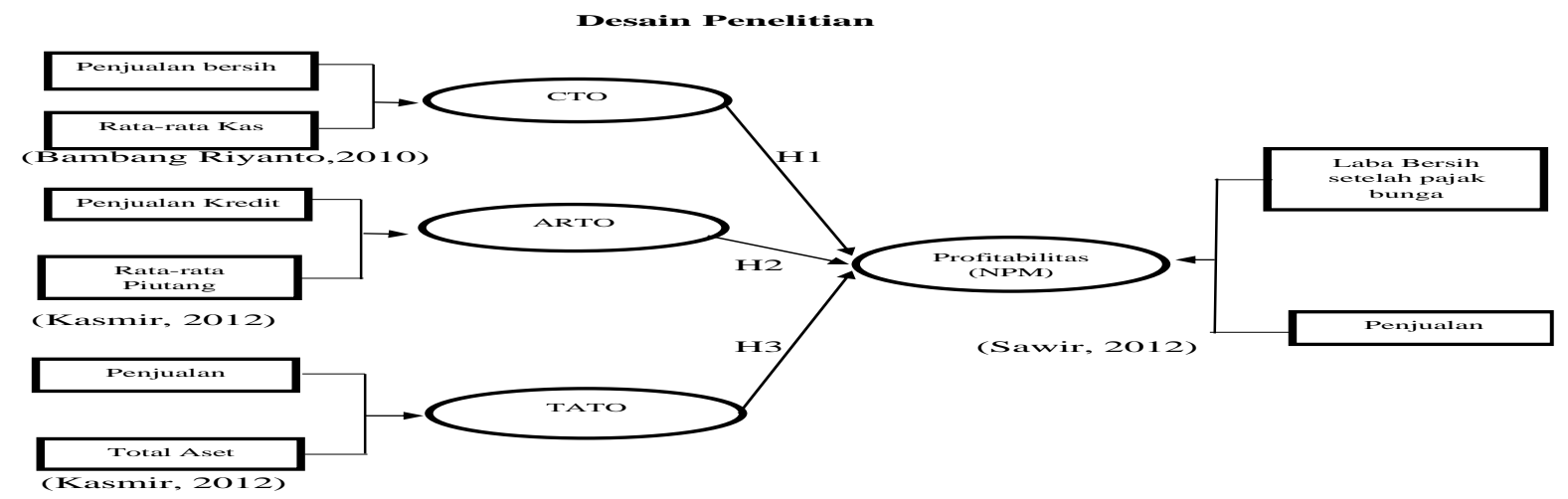

\section{Gambar 2. Desain Penelitian}

Populasi dalam peneltian ini adalah semua perusahaan ritel yang tercatat di Bursa Efek Indonesia selama periode 2017 sampai dengan 2019 yaitu sebanyak 27 perusahaan. Sampel dalam penelitian ini diambil dengan teknik pengambilan sampel metode Purposive Sampling yaitu dengan kriteria-kriteria atau pertimbangan tertentu (Bintarti, 2015). Sehingga didapat 8 perusahaan ritel yang tercatat di Bursa Efek Indonesia dengan mengambil data laporan keuangan per Triwulan selama periode tahun 2017-2019.

Penelitian ini menggunakan analisis statistik deskriptif, analisis regresi data panel, uji asumsi model regresi data panel, dan uji Goodness of Fit (Uji Kesesuaian), yang terdiri dari 
uji secara parsial (Uji t) dan uji secara simultan (Uji F) dan uji koefisisen determinasi $\left(\mathrm{R}^{2}\right)$ sebagai alat pengolahan data menggunakan Eviews 10.

\section{HASIL DAN PEMBAHASAN}

Analisis statistik yang digunakan mengacu pada analisis analisis statistik deskriptif yang digunakan untuk menjelaskan, meringkas, menyederhanakan, mengorganisasi dan menyajikan data secara statistik kedalam bentuk yang teratur dan sederhana agar mudah dibaca dan dipahami. Objek dalam penelitian ini berjumlah 96 data yang terdiri dari data cross-section sebanyak 8 perusahaan dan data time-series sebanyak 3 tahun. Data dalam penelitian ini diambil berdasarkan laporan keuangan per Triwulan (Tiga Bulan) sekali yang telah dikeluarkan dan dipublikasikan oleh masing-masing perusahaan pada website Bursa Efek Indonesia (BEI).

Tabel 1. Analisis Statistik Deskriptif

\begin{tabular}{lcccc}
\hline \hline & NPM & CTO & ARTO & TATO \\
\hline \hline Mean & 0.025363 & 18.70529 & 24.55453 & 1.117942 \\
Median & 0.005050 & 12.61490 & 15.61265 & 0.901200 \\
Maximum & 0.169100 & 77.16700 & 108.5762 & 5.019100 \\
Minimum & -0.099000 & 0.675600 & 0.615800 & 0.000700 \\
Std. Dev. & 0.060160 & 18.17158 & 26.23108 & 0.988904 \\
Skewness & 0.571755 & 1.493378 & 1.786647 & 1.668732 \\
Kurtosis & 2.639867 & 4.775653 & 5.516168 & 6.264680 \\
\hline
\end{tabular}

Sumber: Output Eviews versi.10 diolah. (2020)

Uji normalitas pada model regresi digunakan untuk menguji apakah nilai variabel terdistribusi sercara normal atau tidak. Model regresi yang baik adalah yang memiliki nilai residual yang terdistribusi secara normal. Kriteria pengambilan keputusan dengan Jarque Bera Test yaitu apabila niali probability >0,05. Maka variabel-variabel tersebut terdistribusi normal.

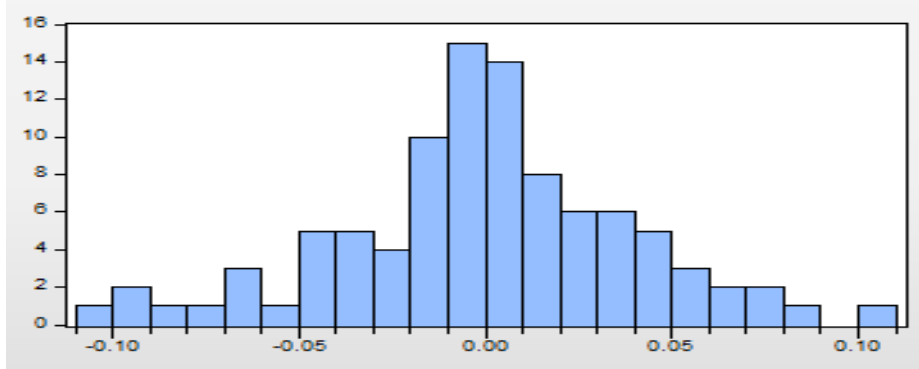

Gambar 3. Uji Normalitas

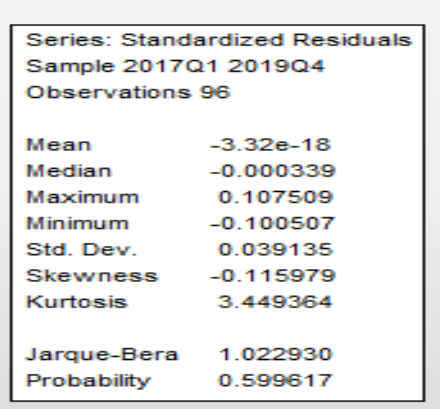

Sumber: Output Eviews statistic versi 10 (2020) 
Berdasarkan uji normalitas di atas, probabilitas sebesar 0,599617 menunjukkan bahwa probability $>0,05$. Sehingga dapat disimpulkan data tersebut terdistribusi secara normal.

Uji multikolonieritas untuk menguji apakah model regresi terdapat korelasi antar variabel bebas atau tidak. Pedoman suatu model regresi yang bebas multikolonieritas adalah mempunyai angka tolerance mendekati 1 . Bebas VIF adalah 10, jika nilai VIF dibawah 10, maka tidak terjadi segala multikolinieritas.

\section{Tabel 2. Uji Multikolinieritas}

\begin{tabular}{|c|c|c|c|}
\hline \multicolumn{4}{|c|}{$\begin{array}{l}\text { Variance Inflation Factors } \\
\text { Date: 08/02/20 Time: 01:09 } \\
\text { Sample: } 196 \\
\text { Included observations: } 96\end{array}$} \\
\hline Variable & $\begin{array}{c}\text { Coefficient } \\
\text { Variance }\end{array}$ & $\begin{array}{c}\text { Uncentered } \\
\text { VIF }\end{array}$ & $\begin{array}{c}\text { Centered } \\
\text { VIF }\end{array}$ \\
\hline $\mathrm{C}$ & 0.000114 & 6.931766 & NA \\
\hline CTO & 0.000063 & 2.586957 & 1.249280 \\
\hline ARTO & 2.61E-08 & 2.031430 & 1.077408 \\
\hline TATO & 2.03E-05 & 2.728396 & 1.190686 \\
\hline
\end{tabular}

Sumber: Output Eviews statistic versi 10 (2020)

Berdasarkan hasil uji multikolonoeritas di atas menunjukan bahwa nilai Centered VIF $\mathrm{X}_{1}$ adalah 1,249280 untuk $\mathrm{X}_{2}$ adalah 1,077408 dan $\mathrm{X}_{3}$ adalah sebesar 1,190686 dimana nilai tersebut kurang dari 10, maka dapat dinyatakan bahwa tidak terdapat masalah multikolinieritas.

Uji Heteroskedestisitas bertujuan untuk menguji apakah dalam model regresi terjadi ketidaksamaan varians dari residual satu pengamatan ke pengamatan yang lain. Kriteria pengujian adalah apabila Prob Obs*R square $>0,05$, maka tidak ada heteroskedestisitas, dan sebaliknya.

\section{Tabel 3. Uji Heteroskedestisitas}

\section{Heteroskedasticity Test: White}

$\begin{array}{llll}\text { F-statistic } & 2.837345 & \text { Prob. F(9,86) } & 0.0057 \\ \text { Obs*R-squared } & 21.97913 & \text { Prob. Chi-Square(9) } & 0.0089 \\ \text { Scaled explained SS } & 24.72105 & \text { Prob. Chi-Square(9) } & 0.0033\end{array}$

Sumber: Output Eviews statistic versi $10(2020)$

Berdasarkan uji heteroskedestisitas diatas dimana nilai Obs*R-squared tersebut bernilai $21,97913>0,05$ maka variabel tersebut tidak memiliki masalah heteroskedestisitas. 
Uji autokorelasi digunakan untuk mengetahui ada atau tidaknya penyimpangan asumsi klasik autokorelasi. Syarat yang harus dipenuhi yaitu tidak adanya autokorelasi dalam model regresi. Uji autokorelasi dalam penelitian ini menggunakan uji Durbin-Watson. Dasar pengambilan keputusan ialah jika Durbin Watson terletak diantara DU dan 4-DU artinya tidak terjadi autokorelasi.

Tabel 4. Uji Autokorelasi

\begin{tabular}{|lllr|}
\hline \multicolumn{4}{|c|}{ Effects Specification } \\
\hline \hline Cross-section fixed (dummy variables) & & \\
\hline \hline R-squared & 0.882432 & Mean dependent var & 0.025363 \\
Adjusted R-squared & 0.868600 & S.D. dependent var & 0.060160 \\
S.E. Of regression & 0.021807 & Akaike info criterion & -4.705674 \\
Sum squared resid & 0.040422 & Schwarz criterion & -4.411842 \\
Log likelihood & 236.8723 & Hannan-Quinn criter. & -4.586902 \\
F-statistic & 63.79842 & Durbin-Watson stat & 1.757866 \\
Prob(F-statistic) & 0.000000 & & \\
\hline
\end{tabular}

Sumber: Output Eviews statistic versi 10 (2020)

Berdasarkan data diatas didapatkan nilai Durbin Watson sebesar 2,054026., maka didapatkan nilai batas atas atau Durbin Upper (dU) sebesar 1,7326 dan batas bawah Durbin Lower (dL) sebesar 1,6039. Berdasarkan hasil perhitungan Durbin-Watson, posisi DW berada diantara dU dengan (4-dU), sehingga pada model ini tidak terjadi autokorelasi.

\section{Hasil Analisis Regresi Linear Berganda.}

Pemilihan tiga model dalam regresi linear berganda dilakukan dengan tiga uji, yaitu:

1. Uji Chow digunakan untuk memilih apakah model Common Effect atau Fixed Effect yang lebih tepat digunakan. Uji Chow dilakukan dengan hipotesis sebagai berikut:

$\mathrm{H}_{0} \quad$ : Common Effect Model (pooled OLS)

$\mathrm{H}_{1} \quad$ : Fixed Effect Model (LSDV)

Tabel 5. Hasil Uji Chow

Redundant Fixed Effects Tests

Equation: Untitled

Test cross-section fixed effects

\begin{tabular}{lrrr}
\hline Effects Test & Statistic & d.f. & Prob. \\
\hline Cross-section F & 31.563773 & $(7,85)$ & 0.0000 \\
\hline Cross-section Chi-square & 122.952835 & 7 & 0.0000
\end{tabular}

Sumber: Output eviews v.10 diolah (2020)

Hasil output dari uji Chow pada Tabel 5 diketahui bahwa nilai probabilitas crosssection $\mathrm{F}$ adalah 0,0000 atau $<0,05$ artinya $\mathrm{H}_{0}$ ditolak. Dengan demikian $\mathrm{H}_{1}$ diterima, $\mathrm{H}_{1}$ pada 
uji Chow adalah Fixed Effect Model, maka menurut uji Chow model yang tepat untuk uji data panel ini adalah Fixed Effect Model.

2. Uji Hausman digunakan untuk memilih apakah Fixed Effect Model atau Random Effect Model yang paling tepat digunakan. Uji Hausman dilakukan dengan hipotesis sebagai berikut:

$\begin{array}{ll}\mathrm{H}_{0} & : \text { Random Effect Model } \\ \mathrm{H}_{1} & : \text { Fixed Effect Model }\end{array}$

Tabel 6. Hasil Uji Hausman

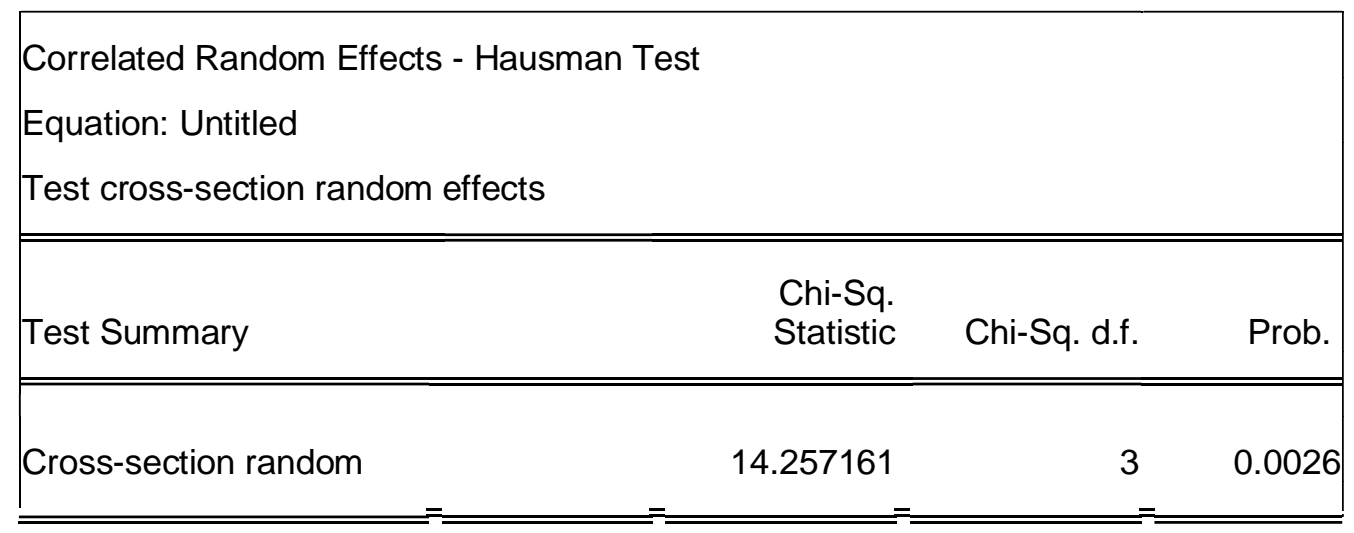

Sumber: Output eviews v.10 diolah (2020)

Berdasarkan hasil uji Hausman di atas, dapat dilihat nilai probabilitas Cross-section random $=0,0026$. Dengan nilai $p$-value yang lebih kecil dari $\alpha(0,05)$, maka kesimpulan dari uji Hausman adalah $\mathrm{H}_{1}$ diterima dan $\mathrm{H}_{0}$ ditolak sehingga model yang lebih baik digunakan dalam penelitian ini adalah Fixed Effect Model (FEM).

Setelah dilakukan estimasi model data panel, yaitu uji Chow dan uji Hausman, maka agar lebih jelas dan ringkas dilakukan eliminasi model yang dapat dilihat pada tabel berikut ini:

Tabel 7. Eliminasi Model Terpilih

\begin{tabular}{cccc}
\hline No & Metode & Model yang dibandingkan & Model yang terpilih \\
\hline 1 & Uji Chow & CEM $><$ FEM & FEM \\
2 & Uji Hausman & FEM $><$ REM & FEM \\
\hline
\end{tabular}

Sumber: Data diolah (2020)

Berdasarkan tabel di atas dari hasil kedua uji tersebut maka model yang paling cocok untuk dipilih dalam penelitian ini adala Model Fixed Effect. 
Tabel 8. Model Regresi Data Panel

Dependent Variable: NPM

Method: Panel Least Squares

Date: 08/02/20 Time: 01:15

Sample: 2017Q1 2019Q4

Periods included: 12

Cross-sections included: 8

Total panel (balanced) observations: 96

\begin{tabular}{|c|c|c|c|c|}
\hline Variable & Coefficient & Std. Error & t-Statistic & Prob. \\
\hline $\mathrm{C}$ & 0.049930 & 0.010742 & 4.648266 & 0.0000 \\
\hline СТO & -0.000453 & 0.000196 & -2.313569 & 0.0231 \\
\hline ARTO & -0.000083 & 0.000192 & -0.434178 & 0.6653 \\
\hline TATO & -0.012565 & 0.004380 & -2.868988 & 0.0052 \\
\hline \multicolumn{5}{|c|}{ Effects Specification } \\
\hline \multicolumn{5}{|c|}{ Cross-section fixed (dummy variables) } \\
\hline R-squared & 0.882432 & \multicolumn{2}{|c|}{ Mean dependent var } & 0.025363 \\
\hline Adjusted R-squared & 0.868600 & \multicolumn{2}{|c|}{ S.D. dependent var } & 0.060160 \\
\hline S.E. of regression & 0.021807 & \multicolumn{2}{|c|}{ Akaike info criterion } & -4.705674 \\
\hline Sum squared resid & 0.040422 & \multicolumn{2}{|c|}{ Schwarz criterion } & -4.411842 \\
\hline Log likelihood & 236.8723 & \multicolumn{2}{|c|}{ Hannan-Quinn criter. } & -4.586902 \\
\hline F-statistic & 63.79842 & \multicolumn{2}{|c|}{ Durbin-Watson stat } & 1.757866 \\
\hline Prob(F-statistic) & 0.000000 & & & \\
\hline
\end{tabular}

Sumber: Output Eviews statistic versi 10 (2020)

Berdasarkan tabel di atas, maka diperoleh persamaan regresi data panel sebagai berikut:

$$
\mathrm{NPM}=0.049930-0.000453 \mathrm{CTO}-0.000083 \text { ARTO }-0.012565 \mathrm{TATO}+\mathrm{e}
$$

Dari persaman regresi tersebut dapat disimpulkan bahwa:

1. Nilai koefisien konstanta sebesar 0.049930 artinya jika variabel $\mathrm{X}_{1}$ (Perputaran kas), $\mathrm{X}_{2}$ (Perputaran piutang), $\mathrm{X}_{3}$ (Perputaran persediaan) adalah nol maka besarnya profitabilitas sebesar 0,049930.

2. Nilai Koefisien regresi variabel $X_{1}$ (Perputaran Kas) bernilai negatif artinya setiap peningkatan $1 \%$ perputaran kas akan menurunkan profitabilitas sebesar -0,000453 dengan asumsi variabel lainnya tetap.

3. Nilai Koefisien regresi variabel $\mathrm{X}_{2}$ (Perputaran piutang) bernilai negatif artinya setiap peningkatan $1 \%$ perputaran piutang akan menurunkan profitabilitas sebesar $-0,000083$ dengan asumsi variabel lainnya tetap.

4. Nilai Koefisien regresi variabel X3 (Perputaran total aktiva) bernilai negatif artinya setiap peningkatan $1 \%$ perputaran total aktiva akan menurunkan profitabilitas sebesar $-0,012565$ dengan asumsi variabel lainnya tetap. 


\section{Hasil Uji Hipotesis Signifikansi Parsial (Uji t)}

1. Perputaran kas terhadap profitabilitas, menyatakan bahwa hasil analisis uji $\mathrm{t}$ dari model regresi diperoleh nilai t hitung bertanda negatif dan lebih kecil dari t tabel $(-2,313569<$ 1,98580) dan nilai probability lebih kecil dari $0,05(0,0231<0,05)$ maka dapat dikatakan bahwa variabel perputaran kas secara parsial berpengaruh negatif dan signifikan terhadap profitabilitas.

2. Perputaran piutang terhadap profitabilitas, menyatakan bahwa hasil analisis uji t dari model regresi diperoleh nilai $\mathrm{t}$ hitung bertanda negatif dan lebih kecil dari t tabel ($0,434178<1,98580)$ dan nilai probability lebih besar dari $0,05(0,6653>0,05)$ maka dapat dikatakan bahwa variabel perputaran piutang secara parsial tidak berpengaruh signifikan terhadap profitabilitas.

3. Perputaran total aset terhadap profitabilitas, menyatakan bahwa hasil analisis uji t dari model regresi diperoleh nilai t hitung bertanda negatif dan lebih kecil dari t tabel ($2,868988<1,98580)$ dan nilai probability lebih kecil dari $0,05(0,0052<0,05)$ maka dapat dikatakan bahwa variabel perputaran piutang secara parsial berpengaruh negatif dan signifikan terhadap profitabilitas.

Berdasarkan hasil dari uji hipotesis penelitian dari data-data yang telah disajikan diatas, maka dilakukan pembahasan hasil penelitian. Hasil-hasil pembahasaan tersebut diantaranya adalah sebagai berikut:

\section{Pengaruh Perputaran Kas $\left(\mathrm{X}_{1}\right)$ terhadap Profitabilitas $(\mathrm{Y})$}

Berdasarkan hasil uji parsial atau uji $\mathrm{t}$ menyatakan perputaran kas secara pasrial berpengaruh negatif dan signifikan terhadap profitabilitas. Artinya semakin tinggi tingkat perputaran kas maka berpengaruh signifikan terhadap profitabilitas Hal ini bisa terjadi disebabkan oleh perusahaan yang kurang menggunakan kasnya untuk menghasilkan penjualan tetapi digunakan untuk kepentingan lain seperti kas digunakan untuk menutupi kerugiankerugian yang ada ataupun hutang piutang serta beban usaha lainnya.

\section{Pengaruh Perputaran Piutang $\left(\mathbf{X}_{2}\right)$ terhadap Profitabilitas $(\mathbf{Y})$}

Dari hasil pengujian yaitu uji parsial menyatakan bahwa perputaran piutang secara parsial tidak berpengaruh terhadap profitabilitas. Walaupun perputaran piutang secara pasrial tidak berpengaruh signifikan terhadap profitabilitas namun perusahaan harus dapat mengelolanya dengan tepat agar tidak terjadi piutang yang tidak tertagih yang akan berdampak terhadap berkurangnya profitabilitas.

\section{Pengaruh Total Aset $\left(\mathbf{X}_{3}\right)$ terhadap Profitabilitas (Y)}

Dari hasil uji parsial atau uji t menunjukan bahwa perputaran total aset (TATO) secara 
parsial berpengaruh negatif dan signifikan terhadap profitabilitas, dibuktikan dengan sebuah fenomena yang terjadi yaitu jika meningkatkan kembali perputaran total aset perusahaan diharapkan selalu efisien dalam hal penggunaan aktiva dalam menghasilkan pendapatan atau penjualan. Karena apabila tidak maka dapat saja terjadi perputaran total aset yang tinggi namun dapat menurunkan tingkat profitabilitas perusahaan dikarenakan aset yang terpakai tidak menciptakan profit atau laba bagi perusahaan.

\section{KESIMPULAN}

Pada bagian akhir ini, penulis akan memaparkan beberapa kesimpulan yang dapat diambil dan saran yang didasarkan pada temuan hasil penelitian. Berdasarkan data yang didapatkan dan pengujian yang telah dilakukan terhadap permasalahan, maka dapat diambil simpulan perputaran kas secara parsial berpengaruh signifikan terhadap profitabilitas pada perusahaan ritel yang tercatat di Bursa Efek Indonesia. Perputaran piutang secara parsial tidak berpengaruh signifikan terhadap profitabilitas pada perusahaan ritel yang tercatat di Bursa Efek Indonesia. Perputaran total aset secara parsial berpengaruh signifikan terhadap profitabilitas pada perusahaan ritel yang tercatat di Bursa Efek Indonesia.

\section{REFERENSI}

Agus, Sartono. (2012). Manajemen Keuangan Teori dan Aplikasi. Edisi Empat. Yogyakarta: BPFE.

Arikunto, S. (2010). Prosedur Penelitian: Suatu Pendekatan Praktik (EdisiRevisi). Jakarta: Rineka Cipta.

Arry Eksandy, dan Vera Mustika Dewi. (2018). Pengaruh Perputaran Modal Kerja, Perputaran Piutang dan Perputaran Kas terhadap Profitabilitas Perusahaan, Studi pada Perusahaan Konstruksi Sektor Infrastruktur di Bursa Efek Indonesia Periode 2012 2015. DINAMIKA UMT, 2 (2), 1-14.

Bintarti, Surya. (2015). Metodologi Penelitian Ekonomi Manajemen. Bekasi: Mitra Wacana Media.

Clairene E.E. Santoso. (2013). Perputaran Modal Kerja dan Perputaran Piutang Pengaruhnya terhadap Profitabilitas pada PT. Pegadaian (Persero). Jurnal EMBA, 1 (4), 1581-1590.

Dantes, Nyoman. (2012). Metode Penelitian. Yogyakarta: Andi.

Elma Natasha Mangayuk, Jullie J. Sondakh, dan I Gede Suwetj. (2019). Pengaruh Perputaran Kas dan Perputaran Persediaan terhadap Tingkat Laba pada Perusahaan Sektor Industri Barang dan Konsumsi yang Terdaftar di BEI periode 2015-2017. Jurnal EMBA, 7 (3), $3608-3617$.

Erlita Oktasari, S.E., M.M (2014). Pengaruh Perputaran Kas dan Perputaran Piutang terhadap Profitabilitas pada Perusahaan Dagang yang Tercatat di Bursa Efek Indonesia Periode 2011-2014. Trilogi Akuntansi, 1 (1).

Feibi Teressa Budiang, Sifrid S. Pangemanan, dan Natalia Y. T. Gerungai. (2017). Pengaruh Perputaran Total Aset, Perputaran Piutang dan Perputaran Persediaan terhadap ROA pada Perusahaan Sub Sektor Perdagangan Eceran yang Terdaftar di BEI. Jurnal EMBA 5 (2).

Ghozali, Imam. 2011. Aplikasi Multivariate dengan SPSS. Edisi Ketujuh. Semarang: Badan 
Penerbit Universitas Diponegoro.

L. Rizkiyanti Putri, dan Lucy Sri Musmini. (2013). Pengaruh Perputaran Kas terhadap Profitabilitas pada PT. TIRTA MUMBUL JAYA ABADI SINGARAJA periode 20082012. Jurnal Akuntansi Profesi, 3 (2).

Lucky Nuhroho, Evi Ariyani, dan Akhmad Amien Mastur. (2019). Analisa Pengaruh Peputaran Kas dan Perputaran Piutang terhadap Return on Asset (ROA) pada perusahaan LQ-45 yang terdaftar di BEI tahun 2012 - 2017. Inovbiz Jurnal Inovasi Bisnis, 20-25.

Marco Muscettola. (2014). Cash Conversion Cycle and Firm's Profitability: An Empirical Analysis on a Sample of 4,226 Manufacturing SMEs of Italy. International Journal of Business and Management, 9 (5).

Ni Putu Putri Wirasari, dan Maria M. Ratna Sari. 2016. Pengaruh Perputaran Modal Kerja, Perputaran Kas, Perputaran Piutang dan Pertumbuhan Koperasi terhadap Profitabilitas. E-Jurnal Akuntansi Universitas Udayana, 17 (2), 885-912.

Peter Tiong. 2017. Pengaruh Perputaran Piutang terhadap Profitabilitas pada Perusahaan PT Mitra Pinastika Mustika Tbk. Jurnal Manajemen dan Bisnis. 1 (1).

R. Chepi Safei Jumhana, et.al. (2018). Pengaruh Perputaran Kas dan Piutang terhadap Profitabilitas PT Mayora Indah, Tbk. Jurnal KREATIF: Pemasaran, Sumber Daya Manusia dan Keuangan, 6 (2).

Reeve, James M. Warren, Carl S. and Fees, Phillip E. (2005). Acounting: Pengantar Akuntansi. Edisi Kedua Puluh Satu. Jakarta: Salemba Empat.

Rio Widiasmoro. (2017). Pengaruh Perputaran Kas, Perputaran Piutang dan Perputaran Persediaan terhadap Profitabilitas (ROA) pada Perusahaan Manufaktur yang Terdaftar di Bursa Efek Indonesia Tahun 2011-2014. Smoothing, 15 (3).

Riyanto, Bambang. (2010). Dasar-Dasar Pembelanjaan Perusahaan. Edisi Ke-4.Yogyakarta: BPPE.

Riyanto. 2013. Statistik Deskriptif. Yogyakarta: Nuha Medika.

Sarjito Surya, Ruly Ruliana, dan Dedi Rossidi Soetama. (2017). Pengaruh Perputaran Kas dan Perputaran Persediaan terhadap Profitabilitas. Jurnal Ilmu Akuntansi, 10 (2). 